\title{
KREATIVITAS SISWA SMP DALAM PEMECAHAN MASALAH MATEMATIKA TERBUKA DITINJAU DARI GAYA BELAJAR
}

\author{
Moh. Syukron Maftuh \\ Program Studi Pendidikan Matematika, Fakultas Keguruan dan Ilmu Pendidikan, Universitas PGRI Adi Buana \\ Surabaya \\ mtu_hutfam@yahoo.co.id
}

\begin{abstract}
Abstrak
Penelitian ini dilatarbelakangi oleh pemikiran bahwa untuk menghadapi tantangan perkembangan IPTEK diperlukan sumber daya yang memiliki keterampilan tinggi yang melibatkan pemikiran kritis, logis, kreatif dan kemampuan bekerjasama yang baik, tiga komponen kunci yang dinilai dalam berpikir kreatif adalah kefasihan (fluency), fleksibilitas (flexibility) dan kebaruan (novelty). Kefasihan mengacu pada banyaknya ide-ide yang dibuat dalam merespons sebuah perintah. Fleksibilitas tampak pada perubahan-perubahan pendekatan ketika merespons perintah. Kebaruan merupakan keaslian ide yang dibuat dalam merespons perintah. Untuk mengembangkan dan mengasah kemampuan kreativitas siswa, maka siswa harus diperkenalkan dengan masalah-masalah matematika yang terbuka yang memungkinkan memiliki cara-cara yang berbeda dalam penyelesaianya serta memiliki jawaban yang beragam atau bahkan memiliki banyak solusi benar sehingga mampu merangsang peserta didik untuk berpikir kreatif, karena dengan masalahmasalah matematika yang terbuka siswa diharapkan dapat mengaitkan antara konsep yang satu dengan yang lain dan menggunakannya dalam pemecahan masalah. Dalam memecahkan suatu masalah, terdapat informasi yang harus diolah dan diserap dengan baik agar masalah tersebut dapat terselesaikan, aktifitas menyerap, mengatur, dan mengolah informasi disebut, itu yang dikatakan sebagai gaya belajar. Banyak ciri perilaku yang merupakan petunjuk kecenderungan gaya belajar seseorang; yaitu gaya belajar visual, auditori dan kinestetik. Tujuan penelitian ini adalah untuk mendeskripsikan kreatifitas siswa dalam pemecahan masalah matematika terbuka dengan gaya belajar visual, auditori, dan kinestetik. Subjek penelitian ini terdiri dari tiga subjek yang masing-masing memiliki gaya belajar visual, auditori dan kinestetik. Penelitian ini merupakan penelitian diskriptif dengan pendekatan kualitatif. Adapun tahapan penelitian yang digunakan peneliti terdiri dari tiga tahap, yaitu tahap persiapan, tahap pelaksanaan, dan tahap analisis. Hasil penelitian menunjukan subjek dengan gaya belajar visual dalam memecahkan masalah matematika terbuka memenuhi tiga indikator kreativitas; yakni, kefasian, fleksibilitas dan kebaruan. Subjek dengan gaya belajar auditori dalam memecahkan masalah matematika terbuka hanya memenuhi satu indikator kreativitas; yakni kefasihan, sedangkan subjek dengan gaya belajar kinestetik dalam memecahkan masalah matematika terbuka hanya memenuhi satu indikator kreativitas; yakni kefasihan.
\end{abstract}

Kata Kunci: kreativitas, pemecahan masalah matematika terbuka, gaya belajar

\section{PENDAHULUAN}

Matematika merupakan salah satu ilmu dasar dalam mempercepat penguasaan ilmu pengetahuan dan teknologi (IPTEK). Untuk menghadapi tantangan perkembangan IPTEK juga diperlukan sumber daya yang memiliki keterampilan tinggi yang melibatkan pemikiran kritis, logis, kreatif dan kemampuan bekerjasama yang baik.

Pemikiran kreatif merupakan suatu kualitas yang sangat menarik untuk dikaji sampai dunia pendidikan menaruh perhatian terhadap perkembangan kreatifitas yang dimiliki siswa sehingga dimuat dalam salah satu standar kelulusan siswa SMP dan SMA oleh Depdiknas (2016). Kreativitas menurut Lumsdaine (2007) adalah aktivitas otak yang dinamis yang melibatkan mental bawah sadar dan yang sadar yang memproses keduaduanya dan membuat sesuatu
"Creativity is a dynamic, whole brain activity that involves the conscious and subconscious mental processing in both idea generation and making something happen".

Munandar (2009) menyatakan bahwa kreativitas adalah kemampuan untuk melihat atau memikirkan halhal yang luar biasa, tidak lazim, memadukan informasi yang tampaknya tidak berhubungan dan mencetuskan solusi-solusi baru atau gagasan-gagasan baru yang menunjukan kelancaran, keluwesan, dan orisionalitas dalam berpikir. Ciri-ciri kreativitas dapat dibedakan menjadi dua yaitu ciri kognitif (aptitude) dan ciri nonkognitif (nonaptitude). Ciri kognitif dari kreativitas terdiri dari orisinalitas, fleksibilitas dan kelancaran. Sedangkan ciri non-kognitif dari kreativitas meliputi motivasi, 
kepribadian, dan sikap kreatif. Kreativitas yang baik meliputi ciri kognitif maupun ciri non-kognitif merupakan salah satu potensi yang penting untuk dipupuk dan dikembangkan.

Untuk mengembangkan dan mengasah kemampuan kreativitas siswa, maka siswa harus diperkenalkan dengan masalah-masalah matematika yang terbuka yang memungkinkan memiliki cara-cara yang berbeda dalam penyelesaianya serta memiliki jawaban yang beragam atau bahkan memiliki banyak solusi benar sehingga mampu merangsang peserta didik untuk berpikir kreatif. Hal itu, sesuai dengan salah satu tujuan pembelajaran matematika menurut kurikulum 2006 yaitu agar siswa memiliki kemampuan memecahkan masalah. Para ahli pendidikan matematika menyatakan bahwa masalah merupakan pertanyaan yang harus dijawab atau direspon. Namun setiap pertanyaan tidak lantas menjadi sebuah masalah. Suatu pertanyaan akan menjadi masalah jika pertanyaan itu menunjukan adanya suatu tantangan (challenge), yang tidak dapat dipecahkan dengan suatu prosedur rutin (routine procedure) yang sudah diketahui oleh si pelaku.
Silver (1997) menjelaskan cara menilai kreativitas dengan menunjukkan hubungan kreativitas dengan pemecahan masalah. Dikatakan bahwa hubungan kreativitas tidak pada pengajuan masalah sendiri tetapi lebih besar pada saling pengaruh antara pemecahan masalah dan pengajuan masalah. Proses dan produk kegiatan itu dapat menentukan sebuah tingkatan (the extent) kreativitas dengan jelas. Silver menjelaskan bahwa untuk menilai kemampuan berpikir kreatif sering digunakan "The Torrance Tests of Creative Thinking (TTCT)". Tiga komponen kunci yang dinilai dalam berpikir kreatif menggunakan TTCT adalah kefasihan (fluency), fleksibilitas (flexibility) dan kebaruan (novelty). Kefasihan mengacu pada banyaknya ide-ide yang dibuat dalam merespons sebuah perintah. Fleksibilitas tampak pada perubahan-perubahan pendekatan ketika merespons perintah. Kebaruan merupakan keaslian ide yang dibuat dalam merespons perintah. Lebih lanjut Silver (1997) menjelaskan lebih rinci hubungan pemecahan masalah dan pengajuan masalah yang meliputi ketiga komponen utama kreativitas yang dipakai dalam penelitian ini.

Tabel 1. Hubungan Antara Pemecahan Masalah dan Komponen Kreativitas

\begin{tabular}{cl}
\hline Creativity & \multicolumn{1}{c}{ Problem solving } \\
Fluency & $\begin{array}{l}\text { Students explore open-ended problems, with many interpretations, } \\
\text { solution methods or answers }\end{array}$ \\
Flexibility & $\begin{array}{l}\text { Students solve (or express or justify) in one way, then in other ways. } \\
\text { Students discuss many solution methods }\end{array}$ \\
Novelt y & $\begin{array}{l}\text { Students examine many solution methods or answers (expressions or } \\
\text { justification), then generate another that is different }\end{array}$ \\
\hline \hline
\end{tabular}

Disamping itu kreativitas juga dideskripsikan berdasarkan gaya belajar siswa, karena setiap siswa tentu memiliki cara tersendiri untuk memahami, maupun mengelola sebuah informasi dalam memecahkan suatu masalah, meskipun siswa sudah diberikan suatu pembelajaran yang sama belum tentu memiliki pengalaman yang sama antara siswa yang satu dengan yang lainya. Karena setiap siswa bisa saja mengolah informasi dengan cara yang berbeda. Dengan demikian, gaya belajar setiap siswapun bisa berbeda. Banyak orang yang memiliki gaya belajar campuran. Ada pula yang akan menemukan bahwa dirinya memiliki suatu jenis gaya belajar yang dominan dibandingkan jenis yang lainya. Namun, tidak ada suatu komposisi gaya belajar yang lebih unggul dibandingkan yang lainya. Karena gaya belajar adalah suatu cara yang khusus dan biasa dilakukan seseorang dalam memperoleh pengetahuan, ketrampilan atau sikap melalui belajar atau pengalaman. Banyak ciri perilaku yang merupakan petunjuk kecenderungan gaya belajar seseorang; yaitu gaya belajar visual, auditori dan kinestetik. Menurut Brandler dan Grinder (dalam DePorter 2005), kebanyakan orang memiliki ketiga gaya belajar tersebut, namun hampir semua orang cenderung pada salah satu gaya belajar yang ada. Pemilihan gaya belajar yang dianggap lebih baik bergantung dari gaya belajar yang cocok dengan masingmasing individu.

Berdasarkan kenyataan ini, penulis tertarik untuk melihat dan mendeskripsikan bagaimana kreativitas siswa dalam pemecahan masalah matematika terbuka berdasarkan perbedaan gaya belajar.

\section{METODE}

\section{Jenis Penelitian}

Tujuan penelitian adalah untuk mendeskripsikan kreatifitas siswa dalam pemecahan masalah matematika terbuka dengan gaya belajar visual, auditori, dan kinestetik, sehingga penelitian ini dikatakan jenis 
penelitian deskriptif, dan data yang diperoleh dari penelitian ini berupa kata-kata tertulis atau lisan sehingga penelitian ini menggunakan pendekatan kualitatif, jadi penelitian ini adalah penelitian diskriptif dengan pendekatan kualitatif.

\section{Subjek Penelitian}

Subjek penelitian ini adalah 3 siswa kelas VIII MTs Ihyaul Islam Bolo, Ujungpangkah Gresik. yang masingmasing mempunyai gaya belajar Visual, Auditori dan Kinestetik.

\section{Instrumen dan Metode Penelitian}

Penelitian ini, terdapat instrument utama dan pendukung. Instrument utama yaitu peneliti sendiri, karena peneliti sendiri yang mengumpulkan, menganalisis, dan menginterpretasi data. Sedangkan instrument pendukung dalam penelitian ini meliputi: tes gaya belajar yang dikembangkan oleh Chislett \& Chapman (2005), Tugas Pemecahan Masalah (TPM) dan pedoman wancara.

\section{Teknik Pengumpulan Data}

Teknik pengumpulan data pada penelitian ini adalah dengan pemberian soal TPM dan wawancara. Subjek diminta menyelesaikan soal TPM selanjutnya peneliti mewawancarai subjek penelitian secara lebih mendalam guna memverifikasi data hasil tes tertulis. Selain itu, wawancara juga digunakan untuk mmperoleh informasi baru yang mungkin tidak diperoleh saat tes tertulis, karena tidak semua yang dipikirkan siswa mampu dituliskan. Hal ini mungkin dapat terungkap ketika wawancara. Untuk menjamin keabsahan data, peneliti menggunakan teknik triangulasi. Triangulasi yang digunakan adalah triangulasi waktu, karena menurut Sugiyono (2010), waktu seringkali mempengaruhi kredibilitas data. data yang dikumpulkan dengan teknik wawancara pada saat nara sumber masih segar, akan memberikan data yang lebih valid sehingga lebih kredibel. Pada penelitian ini, dilakukan pengumpulan data minimal sebanyak 2 (dua) kali. Jarak antara pengumpulan data pertama dan data kedua adalah satu minggu. Data yang diperoleh kemudian dibandingkan. Data dikatakan valid jika ada konsistensi atau kesamaan pandangan antara data pertama dan data kedua. Jika data yang diperoleh belum valid, maka dilakukan pengumpulan data berulang kali sampai data yang diperoleh valid. Selanjutnya data yang valid digunakan dalam penelitian ini.

\section{Teknik Analisa Data}

Dalam penelitian ini mengacu pada tahapan analisis data kualitatif menurut Miles dan Huberman (1992) sebagai berikut:

\section{a. Tahap Reduksi Data}

Reduksi data diartikan sebagai proses memilih, memusatkan perhatian menyederhanakan, mengabstraksikan dan mentransformasi data kasar yang muncul dari catatan-catatan tertulis di lapangan. Semua data dipilih sesuai dengan kebutuhan dan ditranskrip untuk menjawab pertanyaan penelitian, disederhanakan dan dikelompokkan. Kemudian data hasil wawancara dituangkan secara tertulis. Proses reduksi data diawali dengan menelaah seluruh data yang diperoleh dari berbagai sumber, yaitu dari wawancara dan hasil tugas pemecahan masalah yang diberikan.

\section{b. Penyajian Data}

Penyajian data yang dimaksud disini meliputi mengklasifikasi dan mngidentifikasi data yang diperoleh. Hal ini bertujuan untuk mempermudah memahami apa yang terjadi, merencanakan kerja selanjutnya untuk penarikan kesimpulan dari data yang diperoleh. Jadi data yang dituliskan di sini adalah data yang sudah terkumpul dan terkategorisasi dengan baik dalam bentuk teks yang bersifat naratif yang mengacu pada indikator kreativitas.

\section{c. Penarikan Kesimpulan}

Penarikan kesimpulan yaitu kegiatan merangkum data serta memeriksa kebenaran data yang telah dikumpulkan tentang bagaimana kreativitas siswa.

\section{HASIL DAN PEMBAHASAN}

Dalam penelitian ini terdapat dua jenis data dalam penelitian ini, yakni data hasil pemberian Tugas Pemecahan Masalah (tertulis) dan data hasil wawancara pada subjek penelitian. Proses perolehan data tersebut juga menempuh dua tahap, yakni pemberian TPM-1 dan TPM-2 diikuti dengan pelaksanaan wawancara di setiap akhir pemberian TPM. Proses tersebut dilakukan agar data yang diperoleh dapat diuji keabsahannya, karena penelitian ini menggunakan triangulasi waktu sebagai teknik pengujian keabsahan data. 
Moh. Syukron Maftuh: Kreativitas Siswa SMP dalam Pemecahan Masalah Matematika Terbuka Ditinjau dari Gaya Belajar

Berikut hasil analisis data TPM-1 dengan TPM-2 kemudian diuji keabsaan datanya menggunakan triangulasi waktu yakni mencari kesesuaian data hasil
TPM-1 dengan TPM-2 dengan waktu yang berbeda. Triangulasi yang dimaksud disajikan dalam tabel berikut.

Tabel 2. Paparan Triangulasi Data TPM-1 dan TPM-2 Subjek Visual (SV)

\begin{abstract}
Data TPM-1
Subjek merencanakan untuk mencari luas masingmasing tanah yang akan ditanami strowbery dan wortel dengan menggunakan konsep aljabar.

SV menggambar persegipanjang dengan ukuran panjang $60 \mathrm{~m}$ dan lebar40 $\mathrm{m}$, kemudian dari persegipanjang itu SV menggambar dua bangun, untuk persegipanjang pertama membagi secara vertikal; tiap-tiap bangun memiliki panjang $40 \mathrm{~m}$ dan lebar $30 \mathrm{~m}$. Selanjutnya persegipanjang kedua SV membagi secara horisontal dengan tiap-tiap bangun memiliki panjang $60 \mathrm{~m}$ dan lebar $20 \mathrm{~m}$
\end{abstract}

Untuk membuat bangun datar lain, SV menggunakan cara lain dengan menggambar persegipanjang kemudian membagi persegipanjang itu menjadi 2 bentuk segitiga siku-siku dengan menentukan sisisisinya, selanjutnya menggunakan rumus luas segitiga dan cara kedua SV membagi persegi panjang tersebut menjadi 2 bagian trapesium dengan menentukan ukuran sisi-sisinya kemudian menggunakan rumus luas trapesium

Untuk mendapat bentuk bangun datar berbeda, SV menggambar persegipanjang terlebih dahulu kemudian menentukan sisi yang mencerminkan tanah yang akan dibagi dan SV tidak mengetahui nama bangun yang digambarkanya

\section{Data TPM-2}

Subjek merencanakan untuk mencari luas masing-masing tanah Firman dan luas tanah Aan dengan menggunakan konsep aljabar.

SV menggambar persegipanjang dengan ukuran panjang $100 \mathrm{~m}$ dan lebar $20 \mathrm{~m}$, kemudian SV menggambar dua bangun persegipanjang. Untuk persegipanjang pertama membagi secara vertikal dengan tiap-tiap bangun memiliki panjang $75 \mathrm{~m}$ dan lebar $20 \mathrm{~m}$ untuk luas tanah Firman dan memiliki panjang $25 \mathrm{~m}$ dan lebar $20 \mathrm{~m}$ untuk luas tanah Aan. Selanjutnya persegpanjang kedua SV membagi secara horisontal dengan tiap-tiap bangun memiliki panjang $50 \mathrm{~m}$ dan lebar $10 \mathrm{~m}$ untuk luas tanah Aan dan memiliki panjang $50 \mathrm{~m}$ dan lebar $30 \mathrm{~m}$ untuk luas tanah Firman

Untuk membuat bangun datar lain SV menggunakan cara lain dengan menggambar bentuk persegipanjang kemudian membagi 4 bagian sama besar menjadi segitiga siku-siku dengan dengan menentukan ukuran sisi-sisinya. Selanjutnya menggunakan rumus luas segitiga dan cara kedua SV membagi persegipanjang menjadi 4 bagian yang salah satunya merupakan luas tanah Aan dan dan 3 bagian sisanya adalah luas tanah Firman dengan menggunakan rumus luas persegipanjang

Untuk mendapat bentuk bangun datar berbeda, SV menggambar persegipanjang terlebih dahulu yang mencerminkan tanah yang akan dibagi kemudian SV membuat bangun datar gabungan yaitu dengan mencari luas segitiga sikusiku $500 \mathrm{~m}^{2}$ yang merupakan luas tanah Aan dan sisanya luas tanah Firman $1500 \mathrm{~m}^{2}$ dan SV tidak mengetahui nama bangun untuk luas tanah Firman tersebut

Dari penyajian data di atas, dapat disimpulkan atau disajikan tentang kreativitas SV dalam pemecahan masalah matematika terbuka.

1) Kefasihan

SV menggambar dua bangun datar setelah diperoleh luas untuk masing-masing bangun yang diminta, kemudian SV menggambar persegipanjang dengan membagi persegipanjang tersebut menjadi 2 bagian sama besar dengan cara vertikal dan secara horisontal dengan ukuran sisi-sisinya yang berbeda namun luasnya sama dengan luas bangun yang diketahui.

2) Fleksibilitas

SV membuat bentuk bangun datar lain dengan cara membagi persegipanjang tersebut menjadi bangun datar trapesium, segitiga maupun membagi 4 bagian yang sama besar dengan tiap-tiap ukuran bangun memiliki luas yang sama dengan luas bangun yang diketahui. Sehingga secara keseluruhan subjek membuat dua bentuk bangun yang berbeda yaitu dengan menggunakan konsep luas dari beberapa bangun baik segitiga, persegipanjang maupun trapesium.

3) Kebaruan

SV menggambar bangun datar gabungan yang tidak diketahui nama bangun datarnya karena tidak pernah dilakukan sebelumnya dan tidak pernah diperoleh di kelas.

Terlihat pada tabel di atas, dapat disimpulkan bahwa kreatifitas subjek SV dalam memecahkan masalah matematika terbuka memenuhi tiga indikator kreativitas, yakni kefasihan, fleksibilitas dan kebaruan.

Tabel 3. Paparan Triangulasi Data TPM-1 dan TPM-2 Subjek Auditori (SA)

\section{Data TPM-1 Data TPM-2}

Subjek merencanakan untuk mencari luas masing- Subjek merencanakan untuk mencari luas masing-masing tanah masing tanah yang akan ditanami strowbery dan Firman dan luas tanah Aan dengan menggunakan konsep 


\begin{abstract}
Data TPM-1
wortel dengan menggunakan konsep aljabar.

SV menggambar persegipanjang dengan ukuran panjang $60 \mathrm{~m}$ dan lebar40 $m$, kemudian dari persegipanjang itu SV menggambar dua bangun, untuk persegipanjang pertama membagi secara vertikal; tiap-tiap bangun memiliki panjang $40 \mathrm{~m}$ dan lebar $30 \mathrm{~m}$. Selanjutnya persegipanjang kedua SV membagi secara horisontal dengan tiap-tiap bangun memiliki panjang $60 \mathrm{~m}$ dan lebar $20 \mathrm{~m}$
\end{abstract}

Untuk membuat bangun datar lain, SV menggunakan cara lain dengan menggambar persegipanjang kemudian membagi persegipanjang itu menjadi 2 bentuk segitiga siku-siku dengan menentukan sisisisinya, selanjutnya menggunakan rumus luas segitiga dan cara kedua SV membagi persegi panjang tersebut menjadi 2 bagian trapesium dengan menentukan ukuran sisi-sisinya kemudian menggunakan rumus luas trapesium

Untuk mendapat bentuk bangun datar berbeda, SV menggambar persegipanjang terlebih dahulu kemudian menentukan sisi yang mencerminkan tanah yang akan dibagi dan SV tidak mengetahui nama bangun yang digambarkanya aljabar.

SV menggambar persegipanjang dengan ukuran panjang $100 \mathrm{~m}$ dan lebar $20 \mathrm{~m}$, kemudian SV menggambar dua bangun persegipanjang. Untuk persegipanjang pertama membagi secara vertikal dengan tiap-tiap bangun memiliki panjang $75 \mathrm{~m}$ dan lebar $20 \mathrm{~m}$ untuk luas tanah Firman dan memiliki panjang $25 \mathrm{~m}$ dan lebar $20 \mathrm{~m}$ untuk luas tanah Aan. Selanjutnya persegpanjang kedua SV membagi secara horisontal dengan tiap-tiap bangun memiliki panjang $50 \mathrm{~m}$ dan lebar $10 \mathrm{~m}$ untuk luas tanah Aan dan memiliki panjang $50 \mathrm{~m}$ dan lebar $30 \mathrm{~m}$ untuk luas tanah Firman

Untuk membuat bangun datar lain SV menggunakan cara lain dengan menggambar bentuk persegipanjang kemudian membagi 4 bagian sama besar menjadi segitiga siku-siku dengan dengan menentukan ukuran sisi-sisinya. Selanjutnya menggunakan rumus luas segitiga dan cara kedua SV membagi persegipanjang menjadi 4 bagian yang salah satunya merupakan luas tanah Aan dan dan 3 bagian sisanya adalah luas tanah Firman dengan menggunakan rumus luas persegipanjang

Untuk mendapat bentuk bangun datar berbeda, SV menggambar persegipanjang terlebih dahulu yang mencerminkan tanah yang akan dibagi kemudian SV membuat bangun datar gabungan yaitu dengan mencari luas segitiga sikusiku $500 \mathrm{~m}^{2}$ yang merupakan luas tanah Aan dan sisanya luas tanah Firman $1500 \mathrm{~m}^{2}$ dan SV tidak mengetahui nama bangun untuk luas tanah Firman tersebut

Dari penyajian data di atas, dapat disimpulkan atau disajikan tentang kreativitas SV dalam pemecahan masalah matematika terbuka.

1) Kefasihan

SV menggambar dua bangun datar setelah diperoleh luas untuk masing-masing bangun yang diminta, kemudian SV menggambar persegipanjang dengan membagi persegipanjang tersebut menjadi 2 bagian sama besar dengan cara vertikal dan secara horisontal dengan ukuran sisi-sisinya yang berbeda namun luasnya sama dengan luas bangun yang diketahui.

2) Fleksibilitas

SV membuat bentuk bangun datar lain dengan cara membagi persegipanjang tersebut menjadi bangun datar trapesium, segitiga maupun membagi 4 bagian yang sama besar dengan tiap-tiap ukuran bangun memiliki luas yang sama dengan luas bangun yang diketahui. Sehingga secara keseluruhan subjek membuat dua bentuk bangun yang berbeda yaitu dengan menggunakan konsep luas dari beberapa bangun baik segitiga, persegipanjang maupun trapesium.

3) Kebaruan

SV menggambar bangun datar gabungan yang tidak diketahui nama bangun datarnya karena tidak pernah dilakukan sebelumnya dan tidak pernah diperoleh di kelas.

Terlihat pada tabel di atas, dapat disimpulkan bahwa kreatifitas subjek SV dalam memecahkan masalah matematika terbuka memenuhi tiga indikator kreativitas, yakni kefasihan, fleksibilitas dan kebaruan.

Tabel 4. Paparan Triangulasi Data TPM-1 dan TPM-2 Subjek Kinestetik (SK)

\section{Data TPM-1}

SK merencanakan bentuk bangun dengan mencari luas bangun dengan cara aljabar dan konsep beberapa luas bangun datar lain dengan mencari ukuran sisi-sisinya

Subjek dapat menggambarkan dua bentuk bangun persegipanjang yang akan ditanami wortel dan strowbery yang masing-masing memiliki panjang 40 $m$ dan lebar $30 \mathrm{~m}$. Selanjutnya SK menggambarkan persegi panjang dengan membagi menjadi empat bagian segitiga yang masing-masing bangun

\section{Data TPM-2}

SK merencanakan bentuk bangun dengan mencari luas bangun dengan cara aljabar dan konsep beberapa luas bangun datar lain dengan mencari ukuran sisi-sisinya

Subjek dapat menggambarkan dua bentuk bangun persegi panjang yang masing-masing memiliki panjang $50 \mathrm{~m}$ dan lebar $30 \mathrm{~m}$ untuk luas tanah Firman dan memiliki panjang $50 \mathrm{~m}$ dan lebar $10 \mathrm{~m}$ untuk luas tanah Aan. Selanjutnya SK menggambarkan persegi panjang yang masing-masing bangun memiliki panjang $50 \mathrm{~m}$ dan lebar $10 \mathrm{~m}$ untuk luas tanah Aan 


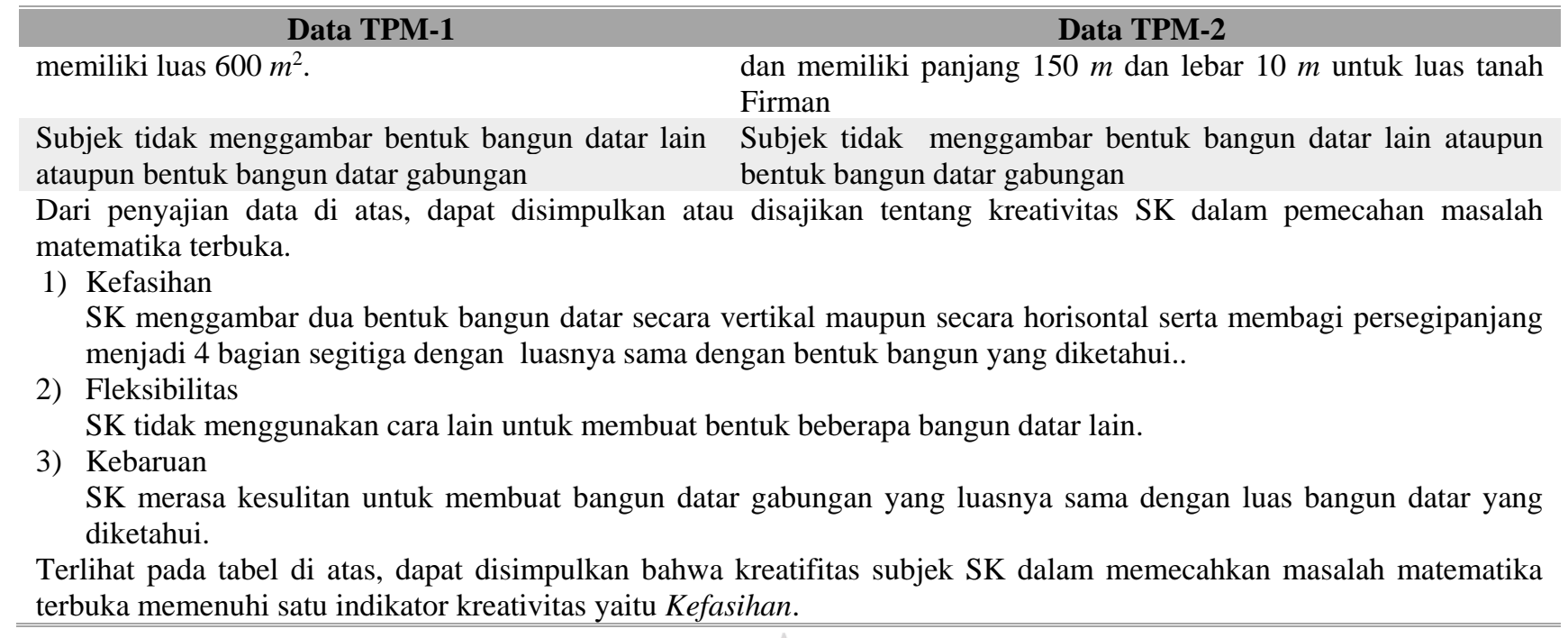

Untuk memudahkan dalam melihat data kreatifitas subjek Visual, Auditori dan Kinestetik dalam memecahkan masalah matematika terbuka, maka disajikan diskripsi kreatifitas subjek dalam pemecahan masalah matematika terbuka berdasarkan perbedaan gaya belajar dalam Tabel 5 sebagai berikut.

Tabel 5. Deskripsi Kreatifitas Subjek Dalam Pemecahan Masalah Matematika Terbuka Berdasarkan Perbedaan Gaya

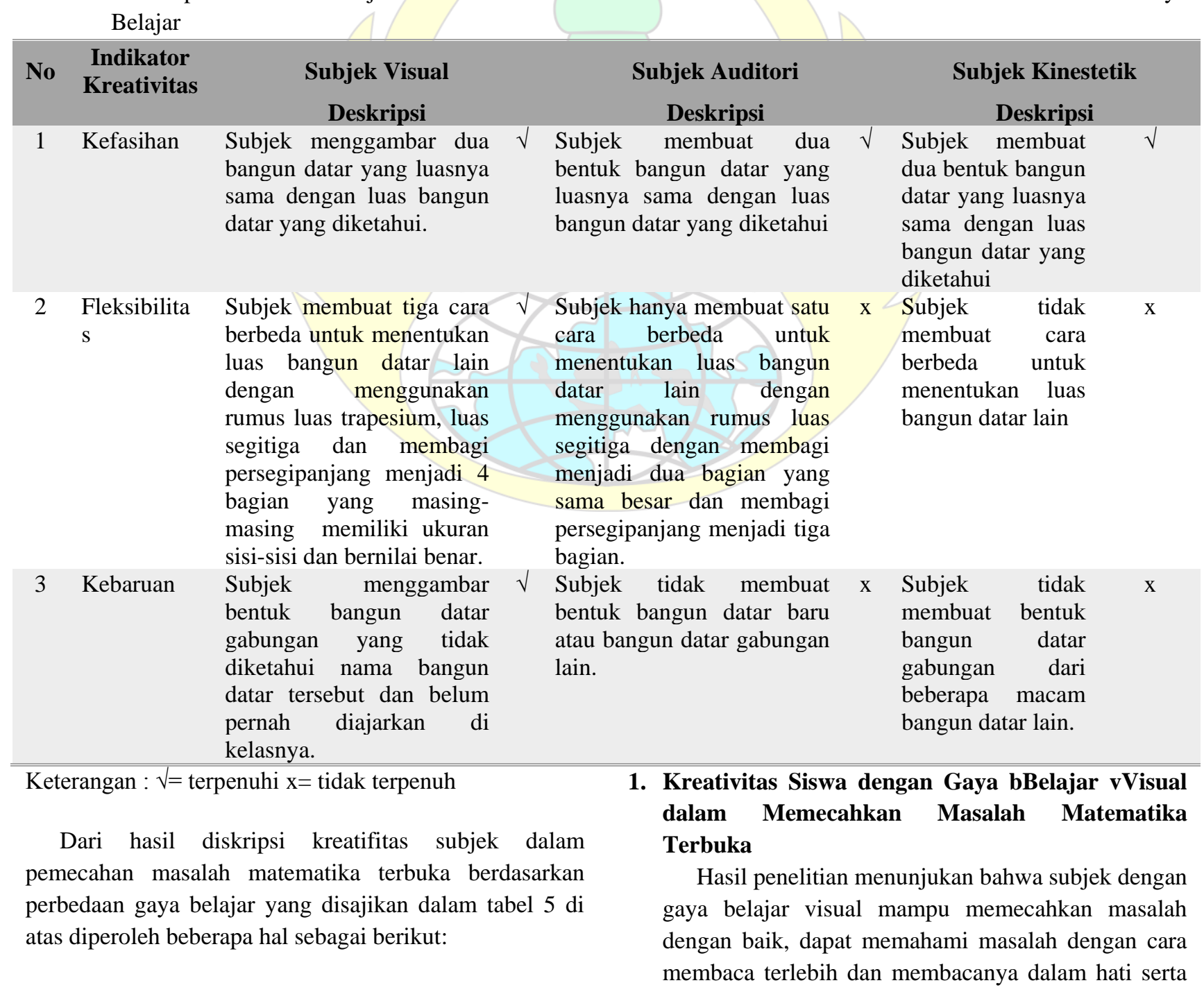


dapat menceritakan kembali maksud dari soal yang ditanyakan. Hal ini sesuai dengan yang diungkapkan DePorter dan Hernacki (2001) bahwa ciri-ciri gaya belajar visual adalah "mengingat dengan asosiasi visual".

Pada TPM-1 dan TPM-2. Subjek dengan gaya belajar visual memenuhi tiga indikator kreativitas yakni kefasihan, fleksibilitas dan kebaruan. Subjek fasih menggambar bentuk bangun datar yang luasnya sama dengan bangun yang diketahui. subjek visual juga fleksibel dalam melakukan pemecahan masalah, karena mampu memecahkan masalah tersebut dengan lebih dari satu cara menggambar bangun datar lain. Selain itu subjek visual juga membuat bentuk bangun datar gabungan yang belum diketahui nama bentuk bangunnya.

2. Kreativitas siswa dengan gaya belajar auditori dalam memecahkan masalah matematika terbuka

Hasil penelitian menunjukan bahwa subjek dengan gaya belajar auditori memahami masalah dengan cara membaca masalah dengan suara perlahan dan sambil menggerakkan bibir, dapat menceritakan kembali masalah dan dapat menyebutkan yang diketahui dan yang ditanyakan dalam masalah sambil sesekali bersuara.. Hal ini sesuai dengan yang diungkapkan DePorter dan Hernacki (2001) bahwa ciri-ciri gaya belajar auditori adalah "menggerakkan bibir dan mengucapkan tulisan dibuku ketika membaca".

Pada TPM-1 dan TPM-2. Subjek dengan gaya belajar auditori hanya memenuhi satu indikator kreativitas yakni kefasihan. Subjek fasih menggambar bentuk bangun datar yang luasnya sama dengan bangun yang diketahui. Subjek hanya memberikan satu cara lain untuk menggambar bentuk bangun datar lain sehingga auditori tidak fleksibel dalam memecahkan masalah. Selain itu auditori juga tidak membuat bentuk bangun datar gabungan.

3. Kreativitas siswa dengan gaya belajar kinestetik dalam memecahkan masalah matematika terbuka

Hasil penelitian menunjukan bahwa subjek dengan gaya belajar kinestetik mampu memecahkan masalah dengan baik, dapat memahami masalah dengan cara membaca dalam hati sambil menggerakkan bolpoin dan penggaris, menunjukkan jari kelembar soal. Hal ini sesuai dengan yang diungkapkan DePorter dan Hernacki (2001) bahwa ciri-ciri gaya belajar kinestetik adalah "menggunakan jari sebagai petunjuk ketika membaca".

Pada TPM-1.1 dan TPM-2.1, Subjek dengan gaya belajar kinestetik hanya mampu memenuhi satu indikator kreativitas yakni kefasihan. Subjek fasih menggambar bentuk bangun datar yang luasnya sama dengan bangun yang diketahui. subjek kinestetik tidak memenuhi indikator fleksibel dalam melakukan pemecahan masalah, karena tidak mampu memecahkan masalah tersebut dengan lebih dari satu cara untuk menggambar bangun datar lain. Selain itu subjek kinestetik juga tidak memenuhi indikator kebaruan karena subjek tidak membuat bentuk bangun datar gabungan.

\section{PENUTUP}

\section{Simpulan}

Kesimpulan yang dapat dikemukakan pada penelitian ini adalah sebagai berikut :

1. Kreativitas siswa dengan gaya belajar visual dalam memecahkan masalah matematika terbuka

a. Kefasihan

Dalam memecahkan masalah pada TPM-1 dan TPM-2, subjek dengan gaya belajar visual mampu menggambar dua bentuk bangun datar beserta ukurannya dengan benar. Sehingga pemecahan masalah matematika yang dibuat oleh subjek tersebut memenuhi indikator kefasihan karena memenuhi indikator penilaian kreativitas dengan baik dan benar.

b. Fleksibilitas

Dalam memecahkan masalah pada TPM-1 dan TPM-2, subjek dengan gaya belajar visual menggunakan cara lain untuk menggambar dua bentuk bangun datar yang telah subjek peroleh sebelumnya dan memiliki luas sama dengan bangun datar yang diketahui. Sehingga pemecahan masalah yang dibuat oleh subjek tersebut memenuhi indikator fleksibilitas.

c. Kebaruan

Dalam memecahkan masalah pada TPM-1 dan TPM-2, subjek dengan gaya belajar visual membuat bangun datar gabungan dari beberapa bangun datar lain dan belum diketahui nama bangun datarnya, Sehingga pemecahan masalah yang dibuat oleh subjek tersebut memenuhi indikator kebaruan.

2. Kreativitas siswa dengan gaya belajar auditori dalam memecahkan masalah matematika terbuka 
a. Kefasihan

Dalam memecahkan masalah pada TPM-1 dan TPM-2, subjek dengan gaya belajar auditori menggambar dua bentuk bangun datar beserta ukurannya dengan benar. Sehingga pemecahan masalah matematika yang dibuat oleh subjek tersebut memenuhi indikator kefasihan karena memenuhi indikator penilaian kreativitas dengan baik dan benar.

b. Fleksibilitas

Dalam memecahkan masalah pada TPM-1 dan TPM-2, subjek dengan gaya belajar auditori menggunakan satu cara lain untuk menggambar bentuk bangun datar yang memiliki luas sama dengan bangun datar yang diketahui. Sehingga pemecahan masalah yang dibuat oleh subjek pada TPM-1 dan TPM-2 tersebut, tidak memenuhi indikator fleksibilitas.

c. Kebaruan

Dalam memecahkan masalah pada TPM-1 dan TPM-2, subjek dengan gaya belajar auditori tidak membuat bangun datar gabungan yang memiliki luas sama dengan bangun datar yang diperoleh sebelumnya. Sehingga pemecahan masalah yang dibuat oleh subjek tersebut tidak memenuhi indikator kebaruan.

3. Kreativitas siswa dengan gaya belajar/kinestetik dalam memecahkan masalah matematika terbuka

a. Kefasihan

Dalam memecahkan masalah pada TPM-1 dan TPM-2, subjek dengan gaya belajar kinestetik menggambar dua bentuk bangun datar beserta ukurannya dengan benar. Sehingga pemecahan masalah matematika yang dibuat oleh subjek tersebut memenuhi indikator kefasihan karena

\section{DAFTAR PUSTAKA}

Arikunto, S. 2011. Dasar - Dasar Evaluasi Pendidikan (Edisi Revisi). Jakarta: PT Bumi Aksara.

Awa, A., Hulukati, E., dan Mohidin, A., D. 2013. Analisis Kemampuan Komunikasi Matematik Siswa Dalam Memahami Volume Bangun Ruang Sisi Datar. [Serial Online]. http://kim.ung.ac.id/index.php/KIMFMIPA/article/do wnload/3388/3364.

Gordah, Eka Kasah. 2015. Analisis Kemampuan Komunikasi Matematis Mahasiswa pada materi memenuhi indikator penilaian kreativitas dengan baik dan benar.

b. Fleksibilitas

Dalam memecahkan masalah pada TPM-1 dan TPM-2, subjek dengan gaya belajar kinestetik tidak menggunakan cara lain untuk menggambar dua bentuk bangun datar yang memiliki luas sama dengan bangun datar yang diketahui. Sehingga pemecahan masalah yang dibuat oleh subjek tersebut tidak memenuhi indikator fleksibilitas.

c. Kebaruan

Dalam memecahkan masalah pada TPM-1 dan TPM-2, subjek dengan gaya belajar kinestetik tidak tidak membuat bangun datar gabungan dari beberapa bangun datar lain, Sehingga pemecahan masalah yang dibuat oleh subjek tersebut tidak memenuhi indikator kebaruan.

Saran

Berdasaarkan hasil penelitian di atas maka dapat disaarankan :

a. Guru hendaknya mampu menciptakan suasana belajar dalam kegiatan pembelajaran dengan menerapkan berbagai variasi metode mengajar yang mengakomodasi berbagai gaya belajar siswa sehingga siswa dapat menyerap materi yang diberikan

b. Guru hendaknya memberikan masalah matematika yang berfariatif pada topik dan masalah-masalah yang menantang untuk menumbuhkan kreativitas siswa secara lebih luas.

c. Perlu dilakukan penelitian lanjutan dengan memperhatikan kelemahan-kelemahan yang ada dalam penelitian ini sehingga diperoleh hasil yang optimal. kuliah Geometri Analitik di Program Studi Pendidikan Matematika IKIP PGRI Pontianak. Jurnal Pendidikan Informatika dan Sains, Vol.4, No.2, Desember 2015

Hamidah. 2012. Pengaruh Self Efficacy Terhadap Kemampuan Komunikasi Matematik. [Serial Online]. http://seminar.uny.ac.id/.../HAMIDAHMakalah-SelfEfficacy.docx.

Moleong, L. 2001. Metodologi Penelitian Kualitatif. Bandung: PT Remaja Rosdyarya. 
NCTM. 2000. Principles and Standards for School Mathematics. Library of Congress Cataloguing-inPublication Data: ISBN: 0-87353-480-8, United States of America.

Nurul, Rizka .2015. Analisis Kemampuan Komunikasi Matematis Siswa Kelas VII C SMP Negeri 1 Rogojampi Tahun Pelajaran 2014/2015. Skripsi. UNEJ.

Sulthani, N., A., Z. 2012. Kemampuan Komunikasi Matematis Siswa Kelas Unggulan Dan Siswa Kelas Reguler Kelas X Sma Panjura Malang Pada Materi Logika Matematika. [Serial Online]. http://jurnalonline.um.ac.id/.../artikelF7D6561652A79 A236FA8430D564300DA.pdf.

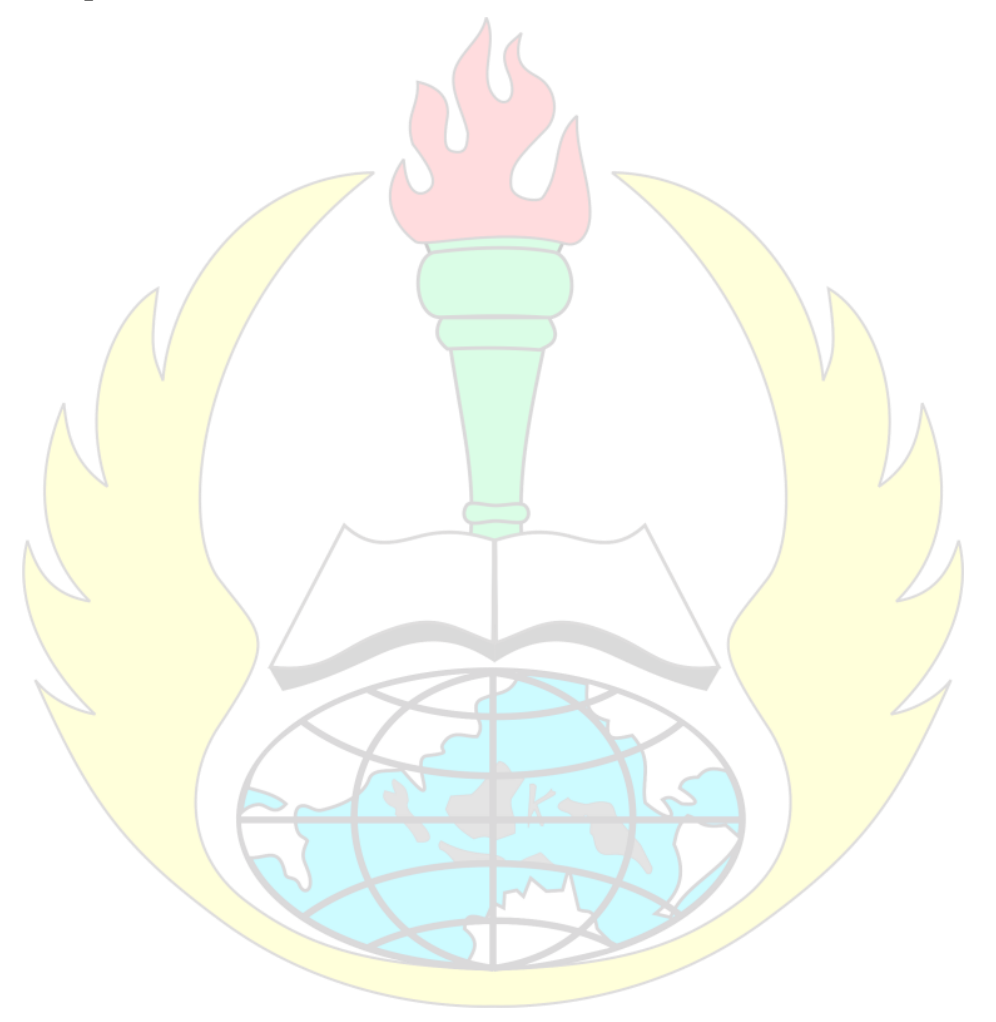


Moh. Syukron Maftuh: Kreativitas Siswa SMP dalam Pemecahan Masalah Matematika Terbuka Ditinjau dari Gaya Belajar

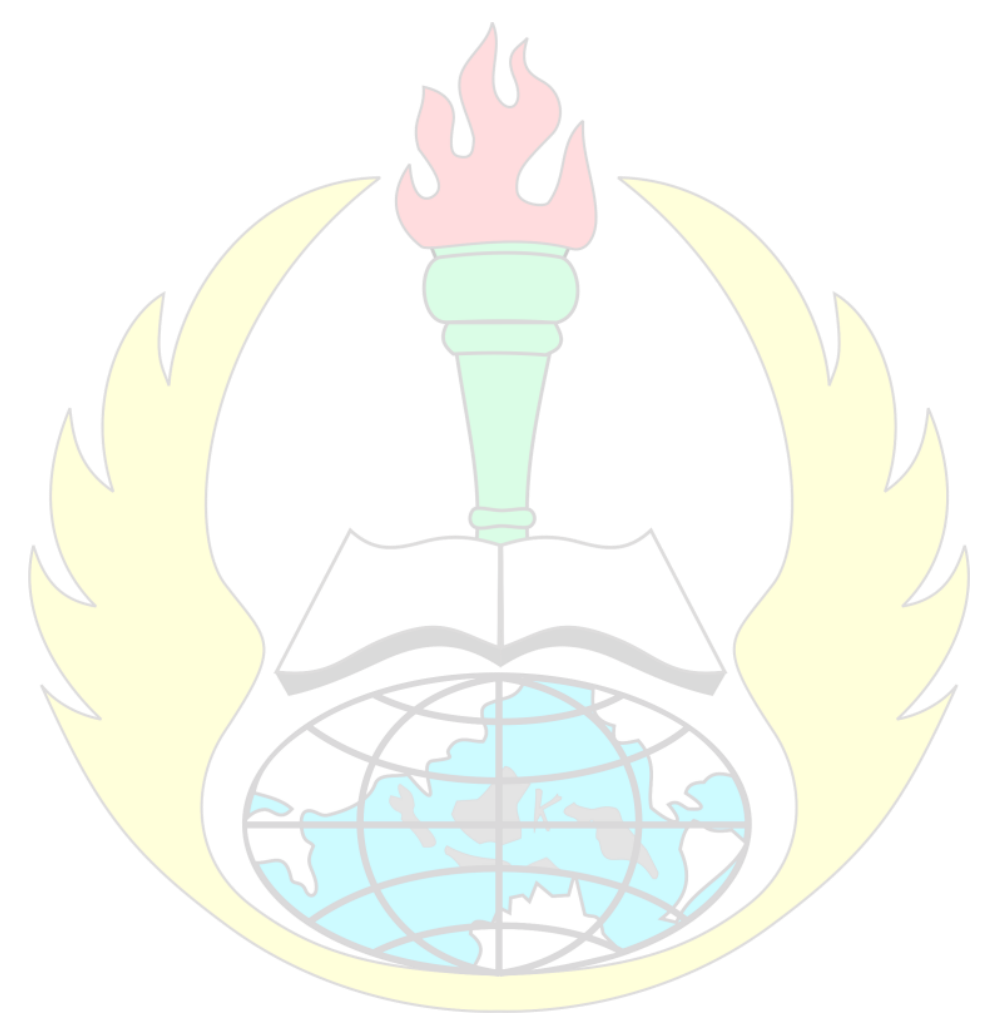

